\section{The Institution of Professional Civil Servants}

THe annual report for 1961 of the Institution of Professional Civil Servants, published in State Service for April 1962, records a membership at December 31, 1961, of 56,927, compared with 53,923 the previous year, but uneasiness about future methods of settling pay in the Civil Service. Government policy over the 'pay pause' is regarded as jeopardizing the work of the Pay Research Unit, but a fresh campaign is to be planned for the recognition of temporary service in full for pension purposes. The recommendations of the Zuckerman Report are still being examined by the Institution, but while any effort to implement the recommendation regarding the transfer of scientists to administrative posts would be welcomed, some of the recommendations are regarded as inconsistent with the concept of a stable career in the Civil Service. Satisfaction is expressed that most of the features in the plans for the new National Reference Library for Science and Invention to which the Institution had objected have now been removed.

\section{The Manchester Museum}

THE most important event of the year 1960-61 at the Manchester Museum was the opening of the gallery containing the extensive and important $R$. W. Lloyd Japanese collection. The lovely ivories, lacquers, examples of sword furniture, etc., have been displayed and lighted so that the incredibly detailed workmanship can be seen to the best advantage. The most interesting temporary exhibition was entitled "Pioneer Research around Manchester", in which an endeavour was made to show, by means of actual apparatus, the experiments and advances made in science and engineering in and near Manchester during the past 200 years. Apparatus of Dalton the chemist, Joule the physicist, OsborneReynolds the engineer was placed with the "Logical Machine" of Jevons the economist. The small chamber in which Rutherford first 'split the atom' was displayed, together with Whitworths' gauges and Royce's first automobile engine.

\section{Colloque Ampère and the Archives des Sciences}

The Colloque Ampère issue, which in former years has been a special supplement of the Archives des Sciences, is this year to become a separate publication and will no longer be incorporated in the Archives. The subscription price for the Archives has been reduced accordingly to 50 Swiss franes per annum, starting with Volume 15, 1962. Subscription forms for the Colloque Ampere issue can be obtained from Prof. G. Béné, Institut de Physique de l'Université, Boulevard d'Yvoy, Geneva, and for the Archives from the Muséum d'Histoire naturelle, Geneva.

\section{The British Society for Parasitology}

AT its annual general meeting during April 3-4, the Parasitology Group (Institute of Biology) was dissolved and the British Society for Parasitology was formed. Membership is open to anyone actively interested in parasitology, and a scheme for founder membership is in operation whereby persons can apply for membership before July 31 , 1962, without having to obtain the signatures of a proposer and seconder. The annual subscription is $£ 1$. Anyone interested in applying for founder membership should write to the honorary general secretary, Dr. J. R. Baker, Department of Parasitology, London School of Hygiene and Tropical Medicine, Keppel Street, London, W.C.1.

\section{The Granada Lectures 1961}

THE annual lectures organized by the British Association for the Advancement of Science and sponsored by Granada Television network are given in Guildhall, London, before an invited audience. A shortened version of each lecture is transmitted on television. During October 1961 the three lectures were given by Sir James Gray on "The Language of Animals", Prof. H. Bondi on "Why Scientists Talk", and Sir John Wolfenden on "The Gap and the Bridge". The lectures have now been published in booklet form (University of London Press. 4s. 6d.).

\section{Society of Chemical Industry : Food Group}

THE following have been elected officers for the Food Group of the Society of Chemical Industry: Chairman, Dr. J. G. Davis; Vice-Chairman, Mr. T. McLachlan; Honorary Treasurer, Mr. R. De Giacomi; Joint Honorary Secretaries, Mr. G. Clewlow and Dr. B. R. J. Thomas; Honorary Recorder, Mr. L. C. Dutton. The following were elected members of the Committee: Mr. W. Price Davis, Dr. H. G. Smith, Mr. H. W. Symons and Mr. G. R. A. Short.

\section{Television Society Premiums}

The Television Society has awarded the following premiums, for outstanding papers read before the Society in 1960-61: the Electronic Engineering Premium, to Mr. I. J. P. James (Research Laboratories, E.M.I., Ltd.) for his paper on "Colour Television Camera Problems"; the E.M.I. Premium, to Dr. W. E. Glenn (General Electric Research Laboratory, Schenectady, New York) for his paper on "Thermoplastic Recording"; the Mervyn Premium, to Dr. D. E. N. King (the Hirst Research Centre, G.E.C.) for his paper on "Transparent Phosphor Screens"; the Mullard Premium, to Mr. D. C. Brothers (B.B.C.) for his paper on "Contrast Law Correction in Television Picture Generators"; the Pye Premium, to Messrs. E. R. Rout and R. F. Vigurs (B.B.C.) for their paper on "A Wide Range Standards Converter"; the T.T.C. Premium, to Dr. H. Barnes (the Marine Station, Millport) for his paper on "Underwater Television in Marine Biology"; the Wireless World Premium, to Mr. J. Roizen (Ampex International, Switzerland) for his paper on "The Use of Video Tape for Colour Television Recording".

\section{Gordon Research Conferences, 1962}

The Gordon Research Conferences, which are aimed at fostering the exchange of ideas and information between research scientists from industrial, Government and academic laboratories, are to be held this year in four residential schools in New Hampshire during the period June 11-August 31 . Forty-two informal conferences, each lasting a week, will be held, their subjects covering a wide range of topics in the physical and biological sciences. Residence and registration charges for a week amount to 100 dollars. Applications should be addressed to, and further information can be obtained from, Dr. W. George Parks, University of Rhode Island, Kingston, Rhode Island.

\section{International Visiting Professorships in Oceano- graphy and Fisheries \\ The Institute of Marine Science, University of} Miami, has established a programme of visiting professorships in all branches of oceanography. Each visitor will offer special lectures and provide instruction and advice to graduate students, for periods 